\title{
Narrative Structure in Martin Amis's London Fields
}

\author{
Ahdieh Akbari (Corresponding author) \\ Department of English Language, Faculty of Foreign Languages, Islamic Azad University \\ Karaj Branch, Iran \\ Tel: +98-911-327-8708Ｅ-mail: ahdieh.Akbari@gmail.com \\ Dr. Mahmood Azizi \\ Department of English Language, Faculty of Foreign Languages, Islamic Azad University \\ Karaj Branch, Iran \\ Tel: +98-9112155034Ｅ-mail: mazizijam@gmail.com \\ Dr. Sima Farshid \\ Department of English Language, Faculty of Foreign Languages, Islamic Azad University \\ Karaj Branch, Iran \\ Tel: +98-9124671721_E-mail: sima_farshid@hotmail.com
}

Received: 12-09- 2012

Accepted: 26-10- 2012

Published: 01-01- 2013

doi:10.7575/ijalel.v.2n.1p.194

URL: http://dx.doi.org/10.7575/ijalel.v.2n.1p.194

\begin{abstract}
Through analyzing the structure of a narrative, the process of character composition with all his or her psychological and physical attributes can be exposed. From the evidence gathered, Martin Amis's novel uses functional narrative strategies in showing different features of the characters specially protagonists. In addition, it has been displayed that the narrative agents are arranged with a special design in both novels to generate various reactions to the characters. The study also has shown that analyzing the structure of a narrative through Genette's arratology help explicate the text and add depth to the meaning that can lead to a new understanding of the novels. The article has aimed to analyze Martin Amis's London Fields according to the representation of Gerard Genette's narratological theories presented in Narrative Discours while doing so, it is intended to reveal functional narrative strategies in showing different features of the characters specially protagonists in these novels.
\end{abstract}

Keywords: order, duration, frequency, mood, voice

\section{Introduction}

The main focus of this article is to penetrate into the structure analysis of the novel according to the categories of Gerard Genette's narratology to reveal functional narrative strategies in showing different features of the characters specially protagonists in the novel. The process of investigation of narrative strategy occurred under the light of the three aspects proposed by Genette, narrative, story, and narrating. The analysis of the mutual relationships among the narrative layers can expose the process of character composition. Each character is observed with all his psychological and physical attributes. Anachronies, ellipses, summaries as well as repetitions and iterations that Genette defines in his narrative model can be designed in such a way that they could give necessary and functional information about characters. As an example, anachronies can provide insight into the process and content of the character's previous experiences. Descriptive pauses can present a detailed picture of the physical and mental state of the character. Repetitions and iterations may alert the reader to the significant facts regarding the character and also give information about the habits and routines of that character. Besides the narrative movements that regulate the narrative time, mood and voice also determine character composition. For example, the things which a character says and the things which other characters say about him as a narrator are designated by the data of the narrative voice. The perspective and the distance which are the agents of the narrative mood may be used functionally as well to control and define a character. With the guidance of these narrative strategies a close narratological examination can expose the factors and conditions that produce a character. 


\section{Discussion}

\subsection{Narrative Order}

London Fields is narrated in two forms, novel and diary form. The diary sections of London Fields are complicated. Many times Samson writes about the weather, his disease, the upcoming crisis, the problems with getting a contract for his novel, his wrecked love life and so on. This analepsis, which gives some information about another story of the past time, will later be used by the reader to develop an understanding of Samson's character. In diary section, the events are narrated as remembered in Samson's mind. So there is no chronological order as are in thoughts and are very disrupted and fragmented. Parts that aren't diary are also fragmented. London Fields is composed of twenty four chapters. Whereas the first twelve chapters are structured around one character at a time, meaning that in each of the first twelve chapters the reader is presented almost exclusively with one character as the focal point, the last twelve are more confusing. Within chapters, the focal point changes from one person to the next without any hints to the reader. There is no chronological order between and within chapters. These breaks in chronology may also simply fulfill a dissenting role, because Amis wishes to disrupt the classical novel's linear representation to some degree.

London Fields is full of passages that are so hard to organize them into a meaningful whole. The process of making sense of the novel is a process of extricating the story from the discourse. In London fields the story of the Samsung Young begins when he arrived in London and lasts until he turns to be the murderer. "The basic story in London Fields is not complicated" and it may seem very trivial and straightforward, it is told in a way that is complicated, "trivial and discontinuous rather than straightforward" (Finny 52). What makes London Fields complicated is the discourse, not the story; A disrupted timeline; an abrupt entering into and exiting from scenes; repetitions of scenes from different points of view, and fragmented notes in Samson's diary are pieces of the puzzle of the discourse, and for the story to be reconstructed, close attention is afforded.

The discordances in time order, anachronies (Genette 35) are the narrative strategies used by Amis to create this fragmented time structure of the novel. Amis uses anachronies in the novel to fulfill different purposes such as introducing the characters especially the protagonist, create an expectation that is to be fulfilled and letting the reader's imagination work.

One of these purposes is that he provides the reader with a surprising, sometimes confusing journey of exploration into characters' personality. It also serves to depict the various periods in the characters' life, movements in time provide the narrating elasticity, expand the character portraiture, and thus introduce several personality traits of the characters. The discordances in time order, anachronies (Genette 35) are the narrative strategies used by Samson to create this fragmented time structure of the novel. For example, the temporal organization of the events in the novel prevents the reader from seeing a unified profile of Samson, the chronology violation helps to present Samson as a man with an unidentified identity.

The most significant anachrony in the novel, which appears in the form of prolepsis, is in the opening of the novel. On the first page, Samson Young, the dying narrator, tries to assess the nature of the story he is about to tell and he informs the reader of the events that are going to happen later in the story and provides the ideal material for the novel:

This is a true story but I can't believe it's really happening. It's a murder story, too. I can't believe my luck.

And a love story (I think), of all strange things, so late in the century, so late in the goddamned day. This is the story of a murder. It hasn't happened yet. But it will (The Note).

The reader cannot identify the protagonists in question with the traditional heroes in literature because though the reader attributes superior qualities to them, he knows that Samson doesn't possess virtues that will indicate his heroism whether in the universe of the novels or in the novelistic tradition in general. The above sentences function as explicit guides to the readers and by telling them Samson is telling the reader what to expect. This also stimulates the reader's curiosity by partially revealing facts that will be obvious later. Samson's first diary entry that is inserted between the table of contents and the first chapter is the other anachrony in the novel appears in the form of analepsis since it goes three days back in time is used to introduce the protagonist to the readers and tell those more about Samson Young. It is an internal analepsis and it is durative since it concerns an entire period during these three days.

Three days ago (is it?) I flew in on a red-eye from New York. I practically had the airplane to myself. I stretched out, calling piteously and frequently to the stewardesses for codeine and cold water. But the red-eye did what a red-eye does. Oh, my. Jesus, I look like the Hound of the Baskervilles... Shaken awake to a sticky bun at 1.30 in the morning, my time, I moved to a window seat and watched through the bright mists the fields forming their regiments, in full parade order, the sad shires, like an army the size of England... (2-4).

One of the techniques that make London Fields complicated is the scene repetitions. Most of the times, when a paragraph in London Fields begins, a lot of effort is needed to find where this segment comes from and if it is related to the rest of the action, when and where it takes place. He confuses the readers by bringing a segment in medias res without any clues about when it is taking place or what is happening. Then later the scene is remembered again with another characters' perspective and more information about the context is given. These parts can be considered as a kind of repeated internal analepsis and completely homodigetic one, since those events occurs before and concerns the elements in the foreground of primary narrative. One example that proves this well, is in chapter ten which Nicola says to Keith: 
"Have you got all that? Are you sure? And for God's sake don't overdo it. Lay it on, but don't overdo it. And mention the globe". And in other parts it is repeated as Keith recalls how he told Guy the message, earlier in the Black Cross and repeats the scene from his perspective: "Anyway she's definitely under the weather. Know what it looked like to me? Apathy. Apathy. Staring out of the window. Playing with that globe thing. Sad little smile on its face. [...] Like - like she was pining. Pining. Pining its little heart out...” The readers just found that a message is delivered, by Keith, from Nicola to Guy (115).

Although just in repeated analepsis, the readers find what the message was, it is not mentioned when she gave him this message and when all these happened.

The other function of anachronies in London fields is the same as Genette's view, "the real function of the internal repeating prolepsis is to create an expectation that is to be fulfilled" (Genette 74). The internal repeating prolepses at the beginning are functional for creating an image of Samson as a good narrator. However, this image disappears, so the protagonist appears as an unreliable one. Anachronies, specially repeated analepsis, give the reader an excellent example of how the characters perceive the actions taking place because the repeated analepsis are narrated from different points of view. In the example given above, it is remarkable how different the two versions of the scene are. In Keith's version (pages 173-177) there is no mentioning of the discussion about Burton Else, which is very dominant in Nicola's version of the conversation (pages 187-191). The reason for the omission is obvious; Keith is losing face in the discussion about Burton Else (Nicola is playing with the framework of Keith's understanding of reality, the tabloid papers), and therefore he has chosen not to report this incident to Samson. The scene repetitions are an excellent means for ironic effects. It gives a precise illustration of the power balance between the characters and is the most dramatic method of displaying Nicola's superiority to Keith and Guy. The contrast between the first account in which Keith feels in control of the situation with the revelation in the second visit to the scene, where it is shown that it is Nicola who is the mastermind, sums up the power balance between the two.

One of the purposes of anachronies which is classified as analepsis and prolepses in London Fields is to introduce the various life periods and personality of Keith to the readers. Along with analipses, there are some prolepses which are much rarer than analipses. Through Genette's explanations, a first-person narrative has a higher potential for the use of anachronies. "By the very fact of its avowedly retrospective character, which authorises the narrator to allude to the future and in particular to his present situation" (1997:94). In a novel such as London Fields, which shifts from third person narrative to first person narrative, this is certainly the case. However sometimes the analepsis or prolepsis cannot be directly attributed to a narrator, instead it may be conveyed through the memories, fears and hopes of a character (Rimmon-Kenan, 1996). "It is only the content of the memory, fear, or hope that constitutes a past, present or future" (Rimmon-Kenan, 1996:51). The narrative of London Fields sometimes occurs within the memories of the character Keith whose memories are of events already passed. Most of the paragraphs in seventh chapter of the novel are about keith's passed memories which can be considered as internal and external analepsis. The purpose of these analepsis is to introduce the various life periods and personality of Keith to the readers.

The other purpose of anachrony in London Fields is letting the reader's imagination work at making the connections adequate to understanding how the scene is to be placed. As the next example shows, a scene can be exited at an especially tense moment, creating a 'cliff-hanger' which compels the reader to keep reading, waiting and expecting the tension to be released. The conversation on page 177 between Keith and Nicola is broken off after Nicola's: '...What?'. The use of italics suggests that Keith's: 'Jim Beam. Benedictine. Porno.' has in some way upset Nicola, and the reader is naturally anxious to see what happens next. Page 191, where the scene is repeated from Nicola's point of view, with more contexts before as well as after the conversation, marks the resolution of a suspense which has added a quality of reading-in-anticipation to the pages in between 177 and 191.

\subsection{Frequency and duration}

The traditional summary and scene succession is replaced with the alternating iterative and singulative narrative in London Fields. The speed and rhythm of the novel is thus determined mainly by the agents of frequency and specifically by iterative structures. The study of the iterative structures spreading over the novel exhibits the fact that these structures together with the elements of duration provide the reader with clues to the personality of the characters. For this reason, the duration and frequency in the novel are analyzed together.

In the first twelve chapters of the novel which are structured around one character at a time, the elements of duration and frequency make the second narrative about each character more attractive than the first narrative. The action proceeds more slowly in the first narrative because of the descriptive scenes of the setting and pauses, whereas the speed of the second narrative is quite fast owing to some summaries, ellipses and iterative passages. Amis uses the frequency and duration to show each character completely.

In the chapters which is about Keith, such as the first one, the action proceeds more slowly in the first narrative because of the descriptive scenes of the setting and detailed description of Keith. But the speed of the second narrative is more slow due to some repeating and iterative passages. When Samson starts to narrate his tale about Keith the speed and rhythm change. The reader is given a full knowledge of Keith's distant past, which gives them a good perception of Keith character. Furthermore, iterative narrating, the result of which is the effective narration of what happened several times with a few words, dominates the novel and introduces the habits and life style of characters specially Keith. In this scene, for example, the iterative and repeating narrating used by Samson illustrates Keith's habits and routines.

Keith Talent was a bad guy. Keith Talent was a very bad guy. You might even say that he was the worst 
guy .......... Intimate encounters with strange-hued women had sweetened him somewhat. His saving graces all had names. What with the Fetnabs and Fatimas he had known, the Nketchis and Iqbalas, the Michikos and Boguslawas, the Ramsarwatees and Rajashwaris - Keith was, in this sense, a man of the world...... After that Keith turned his back on armed robbery once and for all. He took up racketeering.............. Keith worked as a cheat (5).

In this passage the iterative and repeating narrative provides clues to Keith's passion for women, cheating, robbery and racketeering. In the chapter the reader observes better keith's attachment to cheating in the scenes depicting how he spends time in cheating people. In all these scenes people are used as a vehicle to show completely his character. In the following scene the protagonist's attachment to cheating is accentuated by iterative statements.

Keith worked as a cheat. There he stands on the street corner, with three or four colleagues, with three or four fellow cheats; they laugh and cough (they're always coughing) and flap their arms for warmth; they look like terrible birds ... On good days he rose early and put in long hours, going out into the world, into society, with the intention of cheating it. Keith cheated people with his limousine service at airports and train stations; he cheated people with his fake scents and colognes at the pavement stalls of Oxford Street and Bishopsgate (his two main lines were Scandal and Outrage); he cheated people with non-pornographic pornography in the back rooms of short-lease stores; and he cheated people on the street everywhere with the upturned cardboard box or milk crate and the three warped playing cards(6).

The passage demonstrates that the character is a real cheat. Similar to the previously quoted passage, this one reveals Keith's soul in association with his passion for cheating. As Keith himself acknowledges, he can do any kind of cheat (7).

The succession of iterative and singulative narratives and the composition of the inner rhythm of iterative scenes contribute to the other side of Keith's character. They expose Keith's living situation and how this situation influences his character and made him as an abnormal character. To give an example, the narrator describes Keith as:

Keith was used to noise, incessant and unwelcome noise. Most of his life was played out to a soundtrack of sadistic decibelage. Noise, noise - noise on the brink of bearability. He was used to unwelcome nearnesses, also, tostinging proximities; (285).

There is a significant description of the appearance of the protagonist made by Samson in the chapters which are more about Nicola. The portrayal reflects her life style and habits and feelings. In these chapters, the reader also can observe Nicolas's appearance, inner thoughts and feelings better due to the frequent and abundant use of descriptive passages presented through pauses. This descriptive scene provides the reader with a close and realistic observation of the character. Although it is the reader's first direct confrontation with Nicola, he is influenced with the precise and vivid portrayal of her. Most of the time iterative narratives with summaries and ellipses show her well to the readers. The following singulative and iterative narratives introduces her well to the readers:

In the case of Nicola Six, tall, dark, and thirty-four, it was bound up with a delusion, lifelong, and not in itself unmanageable. Right from the start, from the moment that her thoughts began to be consecutive, Nicola knew two strange things. The second strange thing was that she must never tell anyone about the first strange thing. The first strange thing was this: she always knew what was going to happen next. Not all the time (the gift was not obsessively consulted), and not every little detail; but she always knew what was going to happen next (12).

Sam's descriptions in the following iterative narrative with pauses include more straight feelings compared to the previous. Nicola is keen of finding Love. The following description shows her feeling toward love.

Nicola used to think (not often and long ago) that even she might have been saved by love. Love was Plan B. But it never happened. She could attract it, she could bring love in, modern love anyway: she could make a man feel he was at last really living, she could give his world high colour - for a couple of months. But she couldn't generate it, she couldn't send love out. Not even kitten love, curled and purring, with kitty smile. And if love was dead or gone then the self was just self, and had nothing to do all day but work on sex. Oh, and hate and death (192).

Guy Glinch is another character which there are some chapters focused on him. In those chapters, there is a significant description of Guy and His life. The portrayal reflects the narrator's investigation into his life. Comparing to others Sam narrates him as "genuinely delightful human being" and in the chapters named "The Foil" he introduced him with the use of descriptive passages presented through pauses, as:

GUY CLINCH WAS a good guy — or a nice one, anyway. He wanted for nothing and lacked everything. He had a tremendous amount of money, excellent health, handsomeness, height, a capriciously original mind; and he was lifeless. He was wide open. Guy possessed, in Hope Clinch, a wife who was intelligent, efficient (the house was a masterpiece), brightly American (and rich); and then there was the indubitable vigour of the child ... But when he woke up in the morning there was - there was no life. There was only lifelessness (19).

\section{$2.3 \mathrm{Mood}$}

The mood in London fields will be discussed considering its two constituents: distance and perspective. The general analysis of the novel shows that in terms of distance the novel follows a narrative strategy which brings the characters closer to the reader through the reading process. Thus, as the narrative progresses, the reader is given a sense of immediacy and an opportunity to discover the distinctive features of the other character step by step. There are three 
degrees of narrative distance used in this novel, making the narrator seem at times very involved in his narrative, and at times completely absent. These variations and using narrated, transposed and imitated speech add diversity to the act of narrating.

After the examination of perspective in the novel, it becomes clear that the reader confronts the use of variable internal focalization and multiple internal focalizations through four main focal characters: Samson the main narrator, Keith, Nicola, and Guy. Brian Finny mentioned in his book, about Amis's novel, “... all of the characters are authors of one sort or another who are vying with each other to shape events into the form of a story that will count as authoritative" (114) first, the reader sees the events and the other characters through Samson's eyes and then it is through other characters 'perspective. These different perspectives provide the reader with various aspects of each character shown from different perspectives.

Although Samson's comments occasionally work directly on the reader's expectations by making assessments on what is to come but sometimes it does not happen what he said before. Catherine Bernard argues that London Fields features "narrators whose unreliable voices and ambiguous identities should be seen as structural clues to the ontological precariousness of discourse" (Bernard 124). These narrators are "the prismatic and diffracting lenses of the world mad farce, of its loss of meaning, the subversion of the status of the narrator being an index of the questioning of representation at large" (Bernard 126).

The focal point of the novel is not a fixed one within chapters and changes from one person to the other one. In the table of contents, the last twelve chapters are not divided or structured in any way, and this is also true of the chapters themselves. Whereas the first twelve chapters are structured around one character at a time, the last twelve are more confusing. Within chapters, the focal point changes from one person to the next without any hints to the reader, for instance on page 245, action changes in the middle of chapter from Guy to Keith.

In the first part of the novel Samson, the narrator, is focalized that is, the reader sees the events and the other characters through Samson's eyes which he uses different kinds of narrative of words to show them. However, gradually it is shown that he is a narrator with "unreliable voices and ambiguous identities" (Bernard 1124). To call a narrator unreliable we do not need to show him lying or deliberately withholding information, but an unreliable narrator is someone the novel shows you cannot trust for any reason. As Samson, with the following imitated speech, claims about how to narrate the story: 'I think I am less a novelist that a queasy cleric, taking down the minutes of real life' (3). This kind of speech reveals that he is writing about events as they happen with little distance to his story. He is a historian who is writing objectively 'just what happened, nothing more, nothing less'. Whereas what he is really trying to do, are more like guesses because he is using "I think" and "It had better" on the first pages where he is suggesting about the genre. He does not yet have a whole but aimlessly trying to make a copy of life as it occurs before him. He is narrating a story written in Nicola's diary but his great deal of intrusion in the narration of Nicola's story render in each chapter. He is apparently responsible for the discourse of Nicola's story. Based on Nicola's diary, for example, with the use of different imitated speech, Samson guesses that Keith will be Nicola's murderer. 'I found him', it says in her diary, '[on] the Portobello Road, in a place called the Black Cross, I found him' (22), and in this light Samson understands Keith who is put on track for his role as the murderer: 'and murder? The eyes - was there enough blood in them for that? Not now, not yet. He had the talent, somewhere, but he would need the murderee to bring it out. Soon, he would find the lady. Or she would find him' (9). The following quotation of wicked parody also shows that Samson really believes that Keith is the murderer:

'And what about the other Big Occasion? The other Final? Yeah well cheers, Keith. I know he'll go out there and give me two hundred per cent. Keith a quitter? Keith Talent? You must be - Do you want your - ? No danger Keith will bottle it when the cosh comes down. Pressure? He fucking phrives on it' (209).

One of the things which will be clarified through Samson focalization is about an important aspect of Keith personality when he explains Keith's sports monologue on page 91.

I've heard many such summaries from him - of boxing matches, snooker matches, and of course darts matches. At first I thought he just memorized sections of the tabloid sports pages. Absolutely wrong. Remember - he is modern, modern, despite the heels and the flares. When Keith goes to a football match, that misery of stringer's clichés is what he actually sees (97-98).

Through the above imitated speech, which is also a key to the characterisation of Keith Talent the reader finds that he is a "brainwashed product of the tabloid culture" and his identity is a "poor mixture of tabloid headlines and sport commentaries".

Keith is a lower social class and a cheat. The restricted quality of Samson as the narrator and the first focal character of the novel help preserve the distant and incomprehensible image of the Keith. For example, the reader learn much about Keith where Samson relates Keith's behavior with imitated speech (reported speech) (53-54).

I'd been standing under the sign saying TAXIS for about a half-hour when the royal-blue Cavalier made its second circuit and pulled up at the bay. Out he climbed.

Taxi, sir?' he said, and picked up my bag, matter-of-factly, in the line of professional routine.

'That's not a taxi.'

Then he said, 'No danger. You won't get a cab here, pal. No way.' 
I asked for a price and he gave me one: an outlandish sum.

'Limo, innit,' he explained.

'That's not a limo either. It's just a car.'

'We'll go by what's on the clock, yeah?' he said; but I was already climbing into the back and was fast asleep before we pulled away.

I awoke some time later. We were approaching Slough, and the metre said £54.50.

'Slough!'

Until this imitated speech Keith is a mysterious and unattainable character for the reader because there are very few dialogues between Samson and Keith and from and before that he was just describing him with indirect speech. However, this imitated speech excites some hates in the reader for the Keith since it reveals his real character. In this chapter that is full of doubt and weakness the reader could see the tragic nature of Keith because this kind of speech reveals that Keith is a dark person that scared anyone, not just an immoral villain, but a complex and fearful figure.

Guy is the other character who is observed through Samson's focalization. He describes him using following imitated speeches as:

"I am cultivating our third party, the foil, the foal, Guy Clinch, who, to my horror, seems to be a genuinely delightful human being,' (14) ... 'When I take on Chapter 3, when I take on Guy Clinch, I'll have to do, well, not happiness, but goodness, anyway. It's going to be rough' (23).

Samson's first impression given through internal focalization appeals to the reader's interest. Guy is portrayed as a good, healthy and wealthy man through some imitated speeches. By using different speeches he describes him fully. Later he comments differently about him and believes that Guy is capable of murder too. One hint is given on page 162 where Samson, using imitated speech talking about a scene occurring on page 152, warns Nicola not to rely too much on Guy's predictability "Guy is quite capable of surprises, especially when you are concerned. You should have seen him at the darts. Like a lion. I was half-dead with fear". Having different view about characters is the result of being an unreliable narrator.

Guy's identity is made by "hopelessly anachronistic" narratives through the transposed inner speeches in the scene given through Samson's focalization about Guy. The stories show iinnocence; a belief in the reforming influence of high art, and the romantic and idealistic soul looking for life and love in a materialistic world to which he feels increasingly alien. Guy's excessive inhibition in the suppression of his sexuality is almost Victorian; He strongly confronts the occasional extra-marital crushes he finds himself suffering: "It "was like an illness that passed after a couple of weeks; the love virus, efficiently repelled by a determined immune system" (147). Similarly, he frequently fights his lust for Nicola. Mentioning of Guy's chronic physical desire literally crowd the narrative, but he hangs on to a Platonic description of his relationship of Nicola and is unable to acknowledge this other side:

He had this toy of Nicola in his head, oval, blue-backed, like a Victorian miniature. Symbol of the real thing. The real thing. Three brutal jolts would certainly finish it. But all kinds of considerations - including squeamishness, another kind of amour propre, and the thought of all the mess it would leave - combined, as always, to stay his hand (221).

Narrative of the events is given more prominence in the "murderer". In addition, the dialogues that would provide the reader's direct contact with Keith and thus that would reveal important aspects about Keith's character are rare and all the readers have is the information given through narrator about him and this may be not so reliable. The mood is adjusted in this particular way on purpose so as to create a distant character for the reader at the beginning of the novel because in this way Keith is furnished with mystery and attraction and accordingly the reader's curiosity is aroused (Finny 124). Though the presence of the narrator is still apparent in this imitated speech, Keith's thoughts and feelings are at a closer distance and this brings insight into his personality.

Nicola is the other character that some chapters are through her focalization and with this new and stranger perspective the reader rediscovers not only the narrator but also Keith Talent and Guy Clinch. It is significant for the reader to learn about Nicola's personality since she is the most mysterious but powerful character in the novel. It is her diary that gives Samson the idea to follow her story and it is her plan he writes down. Nicola's power to manipulate Samson as well as Keith and Guy and have them, unwittingly, play roles in her personal drama which Sam thought he was only writing down, puts her position in further perspective.

Samson believes that his own life is isolated from the events arranged by Nicola and it is the failure to realise this that is his downfall. Nicola is double-crossing Samson by not telling him of his own involvement. The fact is that Samson is a character in Nicola's story, but he has not realised it from the beginning so he couldn't foreshadow it in the novel he has been writing. On page 466, after Samson has stepped into his story with the following imitated speech and acted the role he was unwittingly assigned by Nicola, he wonders about the novel he has written and in which he is only a disembodied voice and totally improbable as Nicola's murderer: 'I've just taken a casual glance at the beginning - who knows, with a little work, it might accommodate a new ending.' The 'little work' is performed after Samson's death by the simple operation of adding his diary to his novel. In London Fields as a whole, Samson's appearance as the murderer is approved by his diary, which establishes him as a character in Nicola's story and not only the disembodied voice of the narrator. In the chapter which is entitled 'The Script Followed by Guy Clinch' and it is shown through 
several tests that Guy is like a mindless puppet by Nicola and will do exactly what Nicola wants him to do and the story through Nicola's focalization shows that Nicola is working on both Keith and Guy and even Samson to be her murder.

Nicola examines Keith, given through internal focalization, of how much he really believes in the media-created world. After being presented with Burton Else's homosexuality, Keith's whole concept of reality dies: “...for a few seconds he blinked steadily on a heartbeat rhythm". "but if... but then... but he..." Film, Keith, she could have said. Film. All that not real. Not real" (190). The difficulties Keith has with separating TV and reality reach their highpoint when Keith watches the ninety-second TV biodoc on himself. The experience leaves him 'in a state of near-psychotic confusion' (424), and the problems regarding how his wife will interpret the glamorous biodoc, which Nicola has been in charge of constructing, leaves him "clinging to the notion that the biodoc would be screened only at those locations where it had been filmed"(425).

Nicola understands Keith fully and has thereby the power to manipulate him as the reader find it through imitated Speech. First she knows that much of the comic effect derived from the Keith character comes from his ignorant lack of self-reflection regarding the fabricated nature of his personality, Keith, for instance, prefers sex on video where he can fast-forward through the boring bits and go back to the good bits. Nicola learns this and seduces Keith by taping pornographic videos of her. One of these instances shows how much Nicola understands Keith's problems with coping with the problems of separating TV and reality. On page 427 Keith is about to enjoy another one of the videos when Nicola enters the bedroom in the exact same costume she is wearing in the videotaped for Keith. The segment is continued on page 428, where it is revealed that Keith was unable to perform satisfactorily in bed with Nicola. Keith blames his failure on "pressures of darts" (429), whereas Nicola hits the nail on the head: "Yes. And a little difficulty switching from one medium to another. That's what this whole thing is about" (429). Unlike Keith, who thinks that "TV is real" (55), Nicola does not make one ontological state prior to the other; "reality" and "fiction" are both "mediums" in which signs and constructs are open to manipulation.

The reader also observes Guy through Nicola's internal focalization. While Guy is unaware of the fact that he is shaped by anachronisms, Nicola understands this and uses it to manipulate him much in the same way as she does with Keith as it is well shown through imitated and transposed inner speech. She pretends to share Guy's passion for high art and the implicit distinction to mass culture in order to win him over $(145,162)$. As the incident with the Keats lecture (352) for Keith shows, the admiration to the high art which she shows to Guy is just a pretence; in true postmodern spirit, she mixes the codes of high art and mass culture to make her own ends. Nicola films the lecture for Guy to convince him that she is teaching Keith, to add some civilisation to Keith's brutish nature. While Keith is the main victim of the belief that 'TV is real', Guy here also takes the image he sees for a truthful representation.

\subsection{Voice}

The narrative mechanism of London Fields involves many narrative levels embedded within each other. As Brian Finny mentioned

"Amis is drawing attention to the multiplicity of the narrative voices in this book. Sam might be the designated narrator, but Nicola is meant to appear to control the plot and M. A. lurks just off stage reminding us that both Sam and Nicola are narrative mouthpieces with limited autonomy. There is no escaping the problematics of the narrative act in Amis's fiction".

In the beginning of the novel it seems that the novel is Samson's story, but it quickly becomes clear it is Nicola who is in charge of events. The reader has access to her story through the way it is told, that is, via Samson. The detective-like job of extricating the story necessarily goes via the way it is presented to us, the narrative. Even though Nicola 'outwrites' Samson, as well as Keith and Guy (43), her story remains 'his story of her story' (Finney 13). Samson's Story and Nicola's diary makes the multi-layered structure of the novel. Genette states that these short narratives (Diary) embedded within the main narratives compose metadiegeses in London Fields (232). Multiple narrating contribute to the portrayal of Samson as an interesting character. While Some narrative in the form of a diary constitutes the intradiegetic level of the novel, which allows the intimacy between the narrator and the reader, Nicola's narrative constitutes the metadiegetic universe where some diaries appears within a metadiegesis.

Along with Samson Young, there is a mysterious figure of Mark Aspery, another novelist whose flat Samson is living during living in London. The letter at the end of the novel addressed to Aspery shows that Sam has died by the time the novel ends and he has left the novel to him. Nick Bentley in Contemparary British Fiction clarifies this position well as:

It is never clear, therefore, how much of what we are reading is an account of the events that is faithful to Sam's experiences or whether Aspery has added his own alternations. Power over the narrative is, then, removed at least one level from the narrator. It is also significant that Mark Aspery's initials are the same as Martin Amis. However, this is hardly a conventional novel and the reader is persuaded to ask whether these are perhaps Mark Aspery's initials. Later in the novel, Sam notes that Nicola refers to an 'MA' in her diaries, which forces him to speculate: 'Nicola and MA'? Nicola and Mark Aspery?(p 205) 'MA' thus becomes a fluid signifier in the text referring simultaneously to Aspery and to Amis, two novels of external author 'above' Sam's narrative. This would also mean that the fiction does not start on page one, as conventionally assumed, but begins as soon as we open the front cover. In effect, the fictional world is extending beyond the bounds in which it is usually contained and this works at a thematic as well as formal level. Amis seems to be persuading us to think about where fiction begins and, consequently, where it ends (37). 
Samson as a character and narrator appears as the inseparable part of the narrative due to its multi-layered form. That is the protagonist and the narrators are closely related to each other and it is necessary to examine the protagonist and the narrators in relation to each other.A story within a story becomes a narrative strategy that draws the reader into the protagonist's story by arousing curiosity and this many layered narrative in London fields renders the protagonist fabulous. For example, Between chapters twelve and thirteen there are two diary entries. Samson resolves on going to America, hoping to re enlighten the love between himself and his lost love, Missy Harter. These notes written in the form of a diary occur at a meta-metadiegetic level. The reader is presented with direct and sudden glimpses of the protagonist's past experiences, so he is immediately caught up in the protagonist's story. Reliving the past in imagination through meta-metadiegesis creates mystery about the protagonist, as well.

Sam uses prior narrating especially interpolated narrating to tell the story which makes him as unreliable narrator. Whereas M. A. has the novel before him, Samson has little distance to his story and no opportunity to let knowledge of the whole story influence how he shall write the parts; the whole just has not happened yet.Whereas what he is really trying to do, and necessarily so, with his genre suggestions, which are more like guesses (note the '(I think)' and the '(It had better)' on the first page), is to establish a frame of reference in which he can understand the events that are going to happen. Based on Nicola's diary, for example, Samson guesses that Keith will be Nicola's murderer. 'I found him', it says in her diary, '[on] the Portobello Road, in a place called the Black Cross, I found him' (22), and in this light Samson understands Keith who is put on track for his role as the murderer: 'and murder? The eyes - was there enough blood in them for that? Not now, not yet. He had the talent, somewhere, but he would need the murderee to bring it out. Soon, he would find the lady. Or she would find him' (9). The narrative intrusion and the use of interpolated narrating by Samson in this part explicitly works to prepare the reader for Keith as the murderer but at the end Samson's unreliability becomes clear when the reader finds the real murderer.

Samson in London Fields is an intradiegetic narrator since he is a major character in the story he tells (Genette 245). He is usually highly intrusive narrator offering observations to the reader on the action which he is involved. To add to this use of a self-conscious intrusive voice, Amis sometimes introduces what is called "narrative involution" which involves the entry into the fictional world of the author-or, rather, of the fictionalized quasi-author who provides one more persona distancing the author from his creation (Brian Finny 70). Samson's involvement from the beginning to the end of the novel classified him as a intradiegetic - homodiegetic one according to Genette's classification.

\section{Conclusion}

This study has opened new ways for understanding Amis's novel because it has used a practical ways which makes it easier to grasp novel's idea by the way it has directly shown through narrative structure. The investigation of Narrative structure of the novel related to the study of the general behavior of the characters in different situation has been the main focus of this study, while it has led to the categorization of a number of phenomena in the novel all of which have been examined in the light of Gerard Genette's ideas.

It has been found that anachronies, ellipses, summaries as well as repetitions and iterations that Genette defines in his narrative model can be designed in such a way that they could give necessary and functional information about characters. Anachronies have provided insight into the process and content of the character's previous experiences in these two novels. In London Fields the story is straightforward, but the discourse is discontinuous and fragmented. Analepsis and prolepsis gives some information about the story of the past time that later be used can be used by the reader to develop an understanding of Samson's character and make an exploration into his and other characters' personality. It also serves to depict various periods in the characters' life that prevents the reader from seeing a unified profile of Samson, the chronology violation helps to present Samson as a man with an unidentified identity. Descriptive pauses present a detailed picture of the physical and mental state of the characters in London Fields. As an example, in London Fields, Pause which provides a detail consideration of Samson's past, provides the reader a good perception of his character and good perceptions of his character play an important role in understanding of the novel. Through the descriptive pauses and scenes at the beginning of the London Fields, the narrator gives comprehensive information about all characters such as Samson, Nicola, Keith and Guy and setting such descriptions of the Black Cross as a main place that the characters meet each other. Repetitions and iterations alert the reader to the significant facts regarding the character and also give information about the habits and routines of each character. In London Fields. Keith's passion for women, cheating, robbery and racketeering are shown through iterative passages.

Mood and voice also have determined character composition. For example, the things which a character said and the things which other characters said about him as a narrator have been designated by the data of the narrative voice of these novels. The perspective and the distance which are the agents of the narrative mood have been used functionally as well to control and define a character. In London Fields Variable internal focalization and multiple internal focalizations through four main focal characters: Samson the main narrator, Keith, Nicola, and Guy provide the reader with various and sometimes contradictory aspects and of each character shown from different perspectives.

As seen, with the guidance of these narrative strategies a close narratological examination have been exposed the factors and conditions that produce a character in London Fields. 


\section{References}

Amis, M. (1991). London Fields. New York: Vintage.

Bentley, N. (2008). Contemporary British Fiction. Edinbergh: Edinbergh university press.

Bernard, C. (1993). 'Dismembering/Remembering Mimesis: Martin Amis, Graham Swift.'British Postmodern Fiction.Amsterdam: Rodopi, 121-144.

Bertens, H. (2007). Literary Theory TheBasic. Torento: Routledge.

Diedrick, J. (1995). Understanding Martin Amis. Columbia, SC: University of Carolina Press.

Finney, B. (20080. Martin Amis. New York: Routledge.

---. (2006). English Fiction Since 1984: Narrating a Nation.Palgrave Macmilan.

Genette, G. (1980). Narrative Discourse: An Essay in Method. Ithaca: Cornell University Press.

Hawkes, D. (1997). 'Martin Amis.' British Writers.Eds. George Stade and Carol Howard.

NewYork: Scribner's. Supplement IV, 25-44.

Keulks, G. (2006). Martin Amis: Postmodernism and Beyond, London: Palgrave Macmillan, 2006.

Onega, S., Angel, J., \& Landa, G. (1996). .Introduction.Narratology. London, New York: Longman, 1-41.

Tredell, N. (2000). Ed. The Fiction of Martin Amis: A reader's guide to essential criticism. Cambridge: Icon Books. 